\title{
School Factors \& Cumulative Inequality: A Comparative Study of Elementary Education in Pakistan
}

\author{
Afia Kanwal ${ }^{1}$ \\ ${ }^{1}$ Air University, E-9, Islamabad, Pakistan \\ Correspondence: Afia Kanwal, Air University, E-9, Islamabad, Pakistan. E-mail: afiakhere@gmail.com
}

Received: February 5, 2018

Accepted: March 14, 2018 Online Published: April 3, 2018

doi:10.5539/ijel.v8n4p174

URL: https://doi.org/10.5539/ijel.v8n4p174

\begin{abstract}
Stratification is deeply rooted in the networks of educational institutes at both macro and micro level. It leads to difference in accumulation of educational capital. Since the role of equal primary education in development cannot be denied; one of the key skills for success is the "linguistic key"; the English language skill. This paper aims to highlight aspects that lead to disparity among educational institutes and explore differences among Socioeconomically Divided School Systems at elementary level. Specifically this work examines trends in school factors to compare how these factors accumulate to a specific kind of linguistic exposure across socioeconomically divided school systems in Pakistan. In this ethnographic study, cumulative inequality theory of advantage and disadvantage is used as a theoretical framework and data is gathered from 30 elementary schools in Rawalpindi through demographics, teacher interviews and test scores. The results of the research show which factors play a significant role in cumulative advantage or disadvantage. The results are significant for policy makers, educationists, teachers and the larger society.
\end{abstract}

Keywords: linguistic key, curriculum, socioeconomic, divided school systems, ethnographic, cumulative inequality theory

\section{Introduction}

Education in general is associated with development in terms of productivity, modernizations, mobility, social order and equal opportunity Babu (2009). Elementary education is one of the most important asset in a child's early start as it sets defining milestones for the future progress of a society. The role elementary education plays in improving the socioeconomic and cultural development cannot be denied especially for developing countries like Pakistan. Elementary education presents an interesting scenario that is diverse and scattered in scope and faces complex social, cultural, political and economic bottlenecks.

Schools provide a very different environment to children, different from anything they have previously known Pollard (1987). The routines, activities, and organization of school displays a cultural experience unlike any other experience which the children adopt and absorb in terms of educational capital. Bangs \& MacBeath (2010) state that educational capital is incredibly important and it is something we need to provide our children in addition to the classroom experience. Unless schools are equipped with educational and social capital, the gap created not only remains but continues to grow and widen over time. With disparity at large in the system, elementary education not only suffers but influences child progress and human capital development since appropriate skills and cultural exposures vary.

Socioeconomic variations across elementary education in Pakistan directly reflect a system leading to a constant diversification in terms of input and outcomes children produce. This study specially explicates school factors that accumulate to form specific cultural and educational capital in children. In order to improve schooling experience inclusive of all children and maximize outcomes factors that lead to cumulative advantage as opposed to disadvantage, this study vies for providing equal exposure to children across all school systems. The study has a specific focus on comparing English language performance across socially stratified school systems with different educational capital based on the internal mechanisms of everyday school practices and experiences.

\section{Literature Review}

Research has established that stratification is embedded in various educational institutes and plays a major role in providing a specific experience leading to difference in the educational and cultural capital. Bourdieu (1992) 
was of the view that schools reward those who exhibit dominant cultural capital and devalue those with a lesser cultural capital, Carrington (1997). Academic performance, according to McLaren (1995) thus does not represent individuals' competence but the schools depreciation of cultural capital. It is the accumulation of certain capital that influences educational and life trajectories of individuals, Pasco (2003). Marzano (2003) pointed out that schools can be highly effective in enhancing achievement on one hand and conversely highly influential in reducing achievement and leading to failure. Studies also show how certain schools attract bright students and how socioeconomic groups receive different rewards based on their advantaged backgrounds Kincheloe (2007). Hughes \& Kroehler (2002) noted that the effectiveness of schools and academic achievement of students depends not only on the structural inequities but also on what happens in schools. These and numerous other studies highlight how accumulation of specific experience leads to a difference.

The theory of cumulative inequality has been studied and researched on widely mainly by Crystal \& Shea (1990), O' Rand (1996), Ferraro \& Shippee (2009) and Dannefer (2003). It supports the claims that inequalities develop between persons of different socioeconomic classes overtime. Ferraro (2009) said that individuals who are initially advantaged are more likely to receive a good education, leading to good jobs, better health and income benefits, and their personal trajectories are shaped by accumulation of risks, available resources, perceived trajectories, and human agency. Simply put, the theory explains how early advantage leads to accumulation of advantage overtime and how early disadvantage builds on and leads to accumulation of disadvantage. The context in which one exists influences the trajectory path towards success or failure. Similarly, the ability to avert risks involve human agency, all of which if influenced by the accumulated experience can enable a person towards advantageous path.

Since English is the language of empowerment in educational context in developing countries, so the language skills set trends in accumulations of advantage and disadvantage of language competence. The relevance of cumulative inequality theory to language is very strong as it provides important insights from many directions to explain performance and experience differences. Likewise, school factors that lead to linguistic advantage and those that lead to disadvantage are worth exploring in order to improve and equalize educational benefits. A number of studies, for instance, Roeser \& Peck (2003), Hughes \& Kroehler (2002), Rehman (2006), Qadeer (2006), Caro (2009), Lerner \& Steinbern (2009), Shamim (2011), Tamim (2017) show how schools inculcate advantage and mirror socioeconomic divisions of the society to provide unequal absorption of educational and cultural capital. Different researches noted that schools inculcate different forms of knowledge that influence the amount of educational and cultural capital children are exposed to. With this practice, different abilities and outcomes are brought about and trends of accumulation towards advantage or disadvantage are set forth. Studies conducted by Hallinger (1996), Kaplan (1999), Moore (2001), Marks (2006), Reynolds (2014) all point to this fact. Specific school factors that influence input and thus outcomes may be internal or external across schools and may include vision, school funding, curricula, teachers, classrooms, staff morale, safety, motivation etc.

\section{Method}

In this ethnographic study, data was gathered from 30 elementary schools in Rawalpindi. Data was delimited to analysis of fifth class language skills across Private, Government \& Public, and Federal schools. Schools were divided into different strata based on the fee that was taken from the children whereas the school social class was determined through demographic information of children and their families. Generally, the schools were categorized as low paid, middle paid and high paid schools in line with the socioeconomic classes which have access to specific schools. The school samples were compared in terms of the school factors based on Marzano's (2003) model with the help of detailed teacher's interview across the sample. Likewise, assessment of 600 language tests was carried out across the schools with respect to the common European framework of reference (CEFR) as measuring criteria for foreign language learners to measure the language achievement.

\section{Results}

\subsection{Linguistic Achievement across Schools}

The linguistic achievement of students was measured with the help of a language test. The test was designed to assess only the speaking and writing skills of students across the sample. A total of 600 students of class five performed the test. The test was assessed with respect to the common European framework of reference (CEFR) with a scale of 0 to 10 . The results were sorted out with respect to the outcome of a user and categorized as advanced, developing and beginners. The sample was divided in line with the school socioeconomic class. As mentioned earlier, the schools were divided as high paid, middle paid and low paid schools in line with the students' demographics, hence the test scores too were classified in similar way. 


\section{Language Performance}

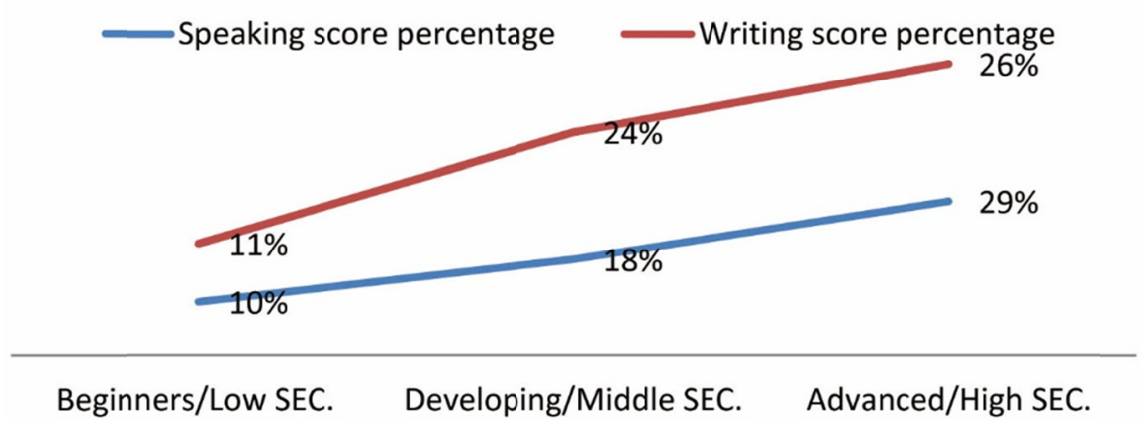

Figure 1. Measure of linguistic performance across SEC

Figure shows the speaking and writing performance across the socially stratified schools systems. A gradient from beginners to advanced level across the socioeconomic classes exists. The low socioeconomic classes that form part of the low paid school systems perform at $10 \%$ speaking skills and $11 \%$ writing skills. The middle socioeconomic class that forms part of the middle paid school systems perform at $18 \%$ speaking skills and $24 \%$ writing skills. The high socioeconomic class that exists in high paid school systems perform at $29 \%$ speaking skills and $26 \%$ writing skills. Overall, there is a major difference of performance across the high, middle and low paid schools in terms of speaking and writing skills.

\subsection{Differences in School Factors across Stratified Schools}

Data gathered through teachers' interviews and observation checklists is in the form of a table that shows differences in school factors across stratified schools (see Appendix A). The table shows a comparison of school factors across high paid, middle paid and low paid schools in terms of school factors. The aspects taken include school visions, curriculum themes, language skills emphasized, language practice, language performance, planning teaching, method/ strategies used, assessment, feedback/ revisions, teacher training, teacher autonomy and satisfaction, teacher/ student interaction, educational resources and facilities, parent and community involvement, safe and orderly environment, high expectations and leadership, collegiality and professionalism.

\subsubsection{Curriculum}

Curriculum varies across school systems in terms of visions and themes (see Appendix A). School visions define the complete process of the kind of input students receive, however, variations clearly point to the fact that the very basic ideological grounds and practices will bring about a different outcome. The study found that curriculum visions varied across school systems. Low paid schools showed an orientation towards purposeful and quality education with a focus on community and national values. Similarly, the curriculum in middle paid schools was orientated towards ethics, religious aspects and a focus on compatibility with the wider world and the high paid schools focused specifically on developing English language skills with improved teaching, management and monitoring. High paid schools had a specific orientation towards meeting standards of the international world.

The language skills emphasized across the schools streams too varied, for instance, low paid schools emphasized on reading and writing, middle paid schools focused on reading, writing and speaking however, high paid schools focused on speaking, listening, reading, and writing. Teachers of middle paid schools pointed out that although speaking skills existed in curriculum as a skill to be emphasized yet, it was not taught or practiced in language classes. The schools were different not only in terms of language performance but in terms of language input and facilities they offered.

\subsubsection{Pedagogy}

Teaching is a very important part of any school system as it has a strong influence on the outcomes. The data based on teaching varied across the socially divided school systems. Teaching was described in terms of planning and organizing teaching content, methods and strategies used to teach language skills, assessment techniques, feedback, teacher students' interaction, teacher training and overall teacher satisfaction across different schools. Teacher responses in low paid schools pointed out that they planned and organized content and conducted regular assessment and revisions. However, onsite observations were contrary to these responses. The 
teaching content was based on textbook lessons and translation method and there was little or no assessment and feedback. Since most low paid schools were supported by Government and non-governmental organizations and provide required teacher trainings and reasonable pays so the teachers were satisfied. Middle paid schools presented a variety of pedagogical experiences to students as each school followed a different plan of conduct. In most of these schools however, teaching was planned and organized along with regular assessment. Teacher student interaction was positive and the methods used were improvised time and again based on the outcomes. Teachers however, showed dissatisfaction, as they did not have trainings and autonomy. High paid schools teaching specifically focused on developing English skill with improved teaching, assessment and feedback. Moreover, these schools had a focus on developing strategies that inculcate independent learning patterns. The teachers however gave neutral responses about overall school satisfaction and autonomy which may mean that they are not satisfied and hence not sure which response to voice.

\subsubsection{Influence of School Factors}

Other school factors that do not seem to have a direct impact on learning outcomes play a very vital role in the overall conduct of a school as pointed out during the interviews with the teachers hence, these factors cannot be ignored. The schools across various socioeconomic divisions exhibited a great difference in the quality of safe and orderly environment, leadership and expectations and collegiality and professionalism. In low paid schools parent and community involvement was found to be very little, in middle paid schools there was an enhanced amount of parent and community involvement whereas in high paid schools there was significant parent and community involvement which was carried out through regular meetings and community based activities. The environment and facilities across the school systems in terms of library material, artwork, flexible space, crowding, water and sanitation facilities, educational facilities and security were compared and these facilities were poor, average and excellent with respect to low, middle and high paid schools. Likewise, the leadership and professionalism was compared with respect to the Marzano's (2003) description of leadership and professionalism. Onsite observations showed that the overall performance of the leaders and the professional environment across the schools varied and the schools principals ranged from poor to excellent leaders. The teacher responses however, pointed out that most of the principals across all school systems were effective communicator, good managers who ensured effective collaboration and monitored classrooms as well as communicated goals to the teachers and cooperated with the staff and parents.

\section{Discussion}

Overall, the data shows a difference in the curriculum experience, language and teaching exposure and skills emphasized across different stratified schools. The high paid, middle paid and low paid schools provide an altogether different curriculum experience, as their visions are different in scope and goals. Schools also provide different material and cultural exposures through a difference in pedagogy related aspects and school factors. Likewise, parental involvement, professionalism, collegiality and environment vary greatly all of which leads to a difference in the performance levels. Since, the sample was exposed to different accumulations of educational and cultural capital hence, it is not surprising that their outcomes vary greatly. The problem however, remains that this difference is not only consistent across the elementary schools but also determinable of how well the students will perform and which future opportunities they will be able to achieve based on a specific linguistic standing.

The study revealed that there is a great influence of school factors, curriculum and pedagogical practices in schools on the language performance of children. High paid schools inculcate specific linguistic exposure that grows towards advantage whereas the gradient of linguistic performance represents a slope with middle and low paid schools performing lesser and moving towards disadvantage. Through a detailed analysis of curriculum, pedagogical and school factors, it is obvious that material and cultural resources too differed across socioeconomic classes. The differences were in line with the overall curriculum visions and the emphasis each curriculum laid on the inculcation of English language. The pedagogical approaches too were found to vary in their approaches to teaching language and there was an emphasis on different language skills across stratified schools. Similarly, the school factors in terms of parental involvement, professionalism, collegiality and environment also varied greatly from being effective to ineffective across schools. These practices resulted in showing how childhood language learning and development, in the form of input took place differently in different stratified school systems that reflect society's distinction of schooling primarily based on economic differences. 


\section{Conclusion}

Finally, the differences regarding how language is perceived introduced, learned and used are more or less the same within a specific social class and school system and quite varied across the systems hence, it can be said that both social and income disparities translate into linguistic disparities through institutional practices. The results of the research are significant for policy makers, educationists, teachers and the larger society. Although, the data is self-sufficient of explaining inequalities of linguistic achievements but what is of crucial value is what should be done with this data in terms of future intervention. The information must be employed to inform future policy and implementation programs, curriculum designs, pedagogical approaches and funding agencies to help people maximize their potential of language skills, in Maxwell's (2012) words, as means to empower and equalize them and to change their perceptions and concept of failure towards constructivism and building participatory societies.

\section{References}

Babu, J. R. (2009). Universalisation of Elementary Education: A Study of District Primary Education Programme from South India. Cambridge: Cambridge Scholars Publishing.

Bangs, J., MacBeath, J., \& Galton, M. (2010). Reinventing schools, reforming teaching: From political visions to classroom reality. London, New York: Routledge.

Caro, D. H. (2009). Socio-Economic Status and Academic Achievement Trajectories from Childhood to Adolescence. Canadian Journal of Education, 32(3), 558-590.

Carrington, V., \& Luke, A. (1997). Literacy and Bourdieu's sociological theory: A reframing. Language and education, 11(2), 96-112. https://doi.org/10.1080/09500789708666721

Crystal, S., \& Shea, D. (1990). Cumulative advantage, cumulative disadvantage, and inequality among elderly people. The Gerontologist, 30(4), 437-443. https://doi.org/10.1093/geront/30.4.437

Dannefer, D. (2003). Cumulative advantage/disadvantage and the life course: Cross-fertilizing age and social science theory. The Journals of Gerontology Series B: Psychological Sciences and Social Sciences, 58(6), S327-S337. https://doi.org/10.1093/geronb/58.6.S327

De Chesnay, M. (2005). Caring for the vulnerable: Perspectives in nursing theory, practice, and research. Burlington: Jones \& Bartlett Learning.

Ferraro, K. F., Shippee, T. P., \& Schafer, M. H. (2009). Cumulative inequality theory for research on aging and the life course. Handbook of theories of aging (pp. 413-433).

Hallinger, P., \& Heck, R. H. (1996). Reassessing the principal's role in school effectiveness: A review of empirical research, 1980-1995. Educational administration quarterly, 32(1), 5-44. https://doi.org/10.1177/0013161X96032001002

Hughes, M., Kroehler, C. J., \& Zanden, J. Y. (2002). Sociology to the core. New York: McGraw Hill companies.

Kaplan, A., \& Maehr, M. L. (1999). Achievement goals and student well-being. Contemporary Educational Psychology, 24(4), 330-358. https://doi.org/10.1006/ceps.1999.0993

Kincheloe \& Steinberg, J. L. (Eds.). (2007). What you don't know about schools. NY, USA. Palgrave Macmillan.

Lerner, R. M., \& Steinberg, L. (2009). Handbook of Adolescent Psychology, Individual Bases of Adolescent Development (Vol. 1). New York: John Wiley \& Sons. https://doi.org/10.1002/9780470479193

Marks, G. N., Cresswell, J., \& Ainley, J. (2006). Explaining socioeconomic inequalities in student achievement: The role of home and school factors. Educational Research and Evaluation, 12(02), 105-128. https://doi.org/10.1080/13803610600587040

Marzano, R. J. (2003). What works in schools: Translating research into action. ASCD, 2003. VA, USA. Desktop Publisher.

Maxwell, J. A. (2012) Qualitative Research Design: An Interactive Approach, 41. Thousand Oak, CA: Sage publications.

McLaren, P. (1995). Critical pedagogy and predatory culture: Oppositional politics in a postmodern era. London: Psychology Press.

Moore, S. (2001). Sociology alive! London: Nelson Thornes.

O'Rand, A. M. (1996). The precious and the precocious: Understanding cumulative disadvantage and cumulative 
advantage over the life course. The Gerontologist, 36(2), 230-238. http://dx.doi.org/10.1093/geront/36.2.230

Pasco, R. J. (2003). Capital and opportunity: A critical ethnography of students at-risk. Lanham, Maryland: University Press of America.

Pollard, A. (Ed.). (1987). Children and Their Primary Schools: a new perspective. London: Psychology Press.

Rahman, T. (2006). Language policy, multilingualism and language vitality in Pakistan. Trends in Linguistics Studies and Monographs, 175, 73.

Reynolds, D., Sammons, P., De Fraine, B., Van Damme, J., Townsend, T., Teddlie, C., \& Stringfield, S. (2014). Educational effectiveness research (EER): A state-of-the-art review. School Effectiveness and School Improvement, 25(2), 197-230. http://dx.doi.org/10.1080/09243453.2014.885458

Roeser, R. W., \& Peck, S. C. (2003). Patterns and pathways of educational achievement across adolescence: A holistic_-developmental perspective. New Directions for Child and Adolescent Development, 2003(101), 39-62. https://doi.org/10.1002/cd.81

Shamim, F. (2011). English as the language for development in Pakistan: Issues, challenges and possible solutions. Dreams and Realities: Developing Countries and the English Language, 291-309.

Tamim, T. (2017). Languages, Symbolic Power and Multidimensional Poverty in the Context of Pakistan. https://doi.org/10.26417/ejls.v9i1.p70-79

\section{Appendix A}

Differences in School Factors Across Stratified Schools: Based on Fee Difference in Pakistani Rupees

\begin{tabular}{|c|c|c|c|}
\hline $\begin{array}{l}\text { SCHOOL } \\
\text { FACTORS }\end{array}$ & $\begin{array}{l}\text { SCHOOLS ACROSS LOWER } \\
\text { STRATA W/ FEE: } 20-500\end{array}$ & $\begin{array}{l}\text { SCHOOLS ACROSS MIDDLE } \\
\text { STRATA W/ FEE: 500-2500/ MIDDLE }\end{array}$ & $\begin{array}{l}\text { SCHOOLS ACROSS HIGHER STRATA } \\
\text { W/ FEE :2500 ONWARDS/ HIGH SC }\end{array}$ \\
\hline School visions & $\begin{array}{l}\text { Purposeful, healthy } \\
\text { educational environment , } \\
\text { national values, community, } \\
\text { learning }\end{array}$ & $\begin{array}{l}\text { Empower and equip,, the country and } \\
\text { the wider world, } \\
\text { affordable, accessible and quality } \\
\text { education, basic knowledge of skills } \\
\text { explorative mind, moral and ethical } \\
\text { values, National objectives, Education } \\
\text { suited to our cultural, historical/ } \\
\text { religious framework }\end{array}$ & $\begin{array}{l}\text { Cambridge, Reggio Emilia approach, } \\
\text { Scottish Curriculum, UK National } \\
\text { Curriculum, international standard, } \\
\text { develop a first language competency of } \\
\text { English, excellence through quality } \\
\text { management, quality teaching, diverse } \\
\text { community, global, development of } \\
\text { attitude, skills, knowledge, high academic } \\
\text { standard, become conscientious citizens of } \\
\text { a greater community, confident, } \\
\text { personally fulfilled }\end{array}$ \\
\hline Curriculum themes & $\begin{array}{l}\text { Patriotism, Religious holidays, } \\
\text { family, school, seasons }\end{array}$ & $\begin{array}{l}\text { Patriotism, Religious holidays, family, } \\
\text { school, basic activities, seasons }\end{array}$ & $\begin{array}{l}\text { Biography, opinions, facts, reading for } \\
\text { entrainment/ expression/ information/ } \\
\text { discussion/ explanation, ethics/priorities }\end{array}$ \\
\hline $\begin{array}{ll}\text { Language } & \text { skills } \\
\text { emphasized } & \\
\end{array}$ & Reading, writing & Reading, writing, speaking & $\begin{array}{l}\text { Speaking, listening, reading, literature, } \\
\text { writing, critical thinking }\end{array}$ \\
\hline $\begin{array}{l}\text { Language practice } \\
\text { Done through }\end{array}$ & $\begin{array}{l}\text { Read and answer, fill in the } \\
\text { blanks, sentence making, } \\
\text { grammar (verbs, adjectives, } \\
\text { nouns, articles, tense, } \\
\text { negatives, interrogatives, } \\
\text { punctuation) } \\
\text { true false, matching lists, } \\
\text { spellings, story writing }\end{array}$ & $\begin{array}{l}\text { Translation, Read and answer, fill in the } \\
\text { blanks, sentence making, vocabulary, } \\
\text { grammar (verbs, adjectives, nouns, } \\
\text { articles, tense, negatives, interrogatives, } \\
\text { punctuation), true false, matching lists, } \\
\text { spellings, translation, essay, story } \\
\text { writing }\end{array}$ & $\begin{array}{l}\text { Activity books, comprehension, proverbs, } \\
\text { idioms, vocabulary, Language rules, } \\
\text { grammar, Functions of language to } \\
\text { dialogue, conversation, responding } \\
\text { critically, speaking, differentiating sounds, } \\
\text { pronunciation w.r.t stress/intonation, } \\
\text { exercises on discovery, Recalling, } \\
\text { brainstorming, planning, sentence } \\
\text { structures, creative/imaginative writing, }\end{array}$ \\
\hline $\begin{array}{l}\text { Language } \\
\text { performance }\end{array}$ & Low & Low to Moderate & Moderate to Excellent \\
\hline
\end{tabular}




\begin{tabular}{|c|c|c|c|}
\hline $\begin{array}{l}\text { Method/ strategies } \\
\text { used }\end{array}$ & $\begin{array}{l}\text { Read and repeat, copy and } \\
\text { memorization, Lecture } \\
\text { method , Less use of } \\
\text { student centered activities and } \\
\text { self-monitoring }\end{array}$ & $\begin{array}{l}\text { Read and repeat, copy and } \\
\text { memorization, Lecture method, Use of } \\
\text { student centered activities and building } \\
\text { strategies, less group activity and } \\
\text { discussion }\end{array}$ & $\begin{array}{l}\text { Communicative method, Mostly Student } \\
\text { centered activities, Thinking exercises, } \\
\text { Focus on group activity, discussion, } \\
\text { self-monitoring and building strategies }\end{array}$ \\
\hline Assessment & $\begin{array}{l}\text { Classroom check, Rare testing, } \\
\text { exams }\end{array}$ & $\begin{array}{l}\text { Classroom check, review homework, } \\
\text { track assessment, testing, exams }\end{array}$ & $\begin{array}{l}\text { Review homework, portfolios } \\
\text { Preparing students for self/peer } \\
\text { assessment, weekly tests, }\end{array}$ \\
\hline Feedback/ revisions & $\begin{array}{l}55 \% \text { give feedback towards } \\
\text { specified outcomes and } \\
\text { revise content }\end{array}$ & $\begin{array}{l}68 \% \text { give feedback towards specified } \\
\text { outcomes and revise content }\end{array}$ & $\begin{array}{l}68 \% \text { give feedback towards specified } \\
\text { outcomes and revise content in case of } \\
\text { difficulty }\end{array}$ \\
\hline Teacher training & $\begin{array}{l}60 \% \text { of teachers receive } \\
\text { training }\end{array}$ & $40 \%$ of teachers receive training & $50 \%$ of teachers receive training \\
\hline $\begin{array}{l}\text { Teacher autonomy } \\
\& \text { satisfaction }\end{array}$ & Highest rate of satisfaction & $\begin{array}{l}\text { Equal rate of satisfaction and } \\
\text { dissatisfaction }\end{array}$ & $\begin{array}{l}\text { Moderate rate of satisfaction and little } \\
\text { percentage of dissatisfaction }\end{array}$ \\
\hline $\begin{array}{l}\text { Teacher/ student } \\
\text { interaction }\end{array}$ & $\begin{array}{l}\text { Only } 8 \% \text { teachers acknowledge } \\
\text { that their students are open } \\
\text { with them whereas } 92 \% \text { do not }\end{array}$ & $\begin{array}{l}\text { Little interaction as } 33 \% \text { teachers } \\
\text { acknowledge that their students are } \\
\text { open with them }\end{array}$ & $\begin{array}{l}\text { More interaction as } 66 \% \\
\text { teacher acknowledge that their students } \\
\text { are open with them }\end{array}$ \\
\hline $\begin{array}{l}\text { Educational } \\
\text { resources } \\
\text { facilities }\end{array}$ & Moderate & Moderate to less & Moderate to sufficient \\
\hline $\begin{array}{l}\text { Parent } \\
\text { community } \\
\text { involvement }\end{array}$ & $5 \%$ & $25 \%$ & $60 \%$ \\
\hline $\begin{array}{l}\text { Safe \& orderly } \\
\text { environment }\end{array}$ & Low & Moderate to less & Moderate to sufficient \\
\hline $\begin{array}{l}\text { Expectations \& } \\
\text { leadership }\end{array}$ & Moderate & Moderate to high & Moderate to high \\
\hline Professionalism & $\begin{array}{l}\text { Low percentage of overall } \\
\text { instructional leadership, } \\
\text { expectations, management and } \\
\text { collegiality }\end{array}$ & $\begin{array}{l}\text { Moderate percentage of overall } \\
\text { instructional leadership, expectations, } \\
\text { management and } \\
\text { collegiality }\end{array}$ & $\begin{array}{l}\text { High percentage of overall instructional } \\
\text { leadership, expectations, management and } \\
\text { collegiality }\end{array}$ \\
\hline
\end{tabular}

Note. A detailed comparison of differences in school factors across stratified schools.

\section{Copyrights}

Copyright for this article is retained by the author(s), with first publication rights granted to the journal.

This is an open-access article distributed under the terms and conditions of the Creative Commons Attribution license (http://creativecommons.org/licenses/by/4.0/). 